Article

\title{
How the Public Shaming of Peers Enhances Corporate Social Performance: Evidence from Blacklisted Firms in Japan
}

\author{
Ranxin Liao and Jungwon Min * \\ Department of Management, Sophia University, 7-1 Kioi-cho, Chiyoda-ku, Tokyo 102-8554, Japan; \\ r-liao-5e5@eagle.sophia.ac.jp \\ * Correspondence: j-min-2k4@sophia.ac.jp
}

check for updates

Citation: Liao, R.; Min, J. How the Public Shaming of Peers Enhances Corporate Social Performance: Evidence from Blacklisted Firms in Japan. Sustainability 2021, 13, 13835 https://doi.org/10.3390/ su132413835

Academic Editor: Włodzimierz Sroka

Received: 10 November 2021

Accepted: 6 December 2021

Published: 14 December 2021

Publisher's Note: MDPI stays neutral with regard to jurisdictional claims in published maps and institutional affiliations.

Copyright: (c) 2021 by the authors. Licensee MDPI, Basel, Switzerland. This article is an open access article distributed under the terms and conditions of the Creative Commons Attribution (CC BY) license (https:/ / creativecommons.org/licenses/by/ $4.0 /)$.

\begin{abstract}
This study aims to show how vicarious public shaming, that is the public disgrace of several peers in the same industry, affects focal firms' corporate social performance (CSP). Drawing on the legitimacy and category theories, we suggest that since an increased vicarious public disgrace harms the legitimacy of the entire industry, peer companies attempt to negate these potential legitimacy losses by improving their CSP. This tendency is more pronounced in firms that have a poor record of CSP. Using a context of the Japanese blacklisted companies by the government for labor law delinquency between 2016 and 2019, our results confirm that vicarious public disgrace is a significant antecedent to improving CSP. Our findings also imply that the appropriate use of public disgrace can enhance overall the CSP levels.
\end{abstract}

Keywords: vicarious public disgrace; corporate social performance (CSP); legitimacy theory; category theory; blacklisted firms

\section{Introduction}

Companies often suffer due to the negative reputation of related firms [1-3]. For example, the nuclear power plants worldwide suffered legitimacy losses after the Chernobyl disaster in 1986 as several stakeholders, including mass media and nonprofit organizations, publicly advocated the risks posed by the nuclear power plant industry [4]. Similarly, following Exxon Valdez's oil spill accident in 1989, several oil companies faced public criticism regarding the potential risks generated by them and were forced to take responsibility in handling the aftermath of such incidents [5]. The spillovers of negative reputation are caused by not only such accidents, but also disgraceful events. For instance, in Japan, the government has been publicly disclosing a monthly list of exploitative firms since 2016 to curb unethical labor practices. This has led to legitimacy losses for peer firms in the same industry without malicious activities, as stakeholders view all firms in the same industry from a similar manner [6,7].

The legitimacy theory in organizational studies has addressed these issues [8,9]. The theory holds that public disgrace is a significant driver of organizational failure because a firm's survival and performance are functions of legitimacy acquisition [10,11]. However, the literature has mainly focused on disgraced firms and their reactions [12,13], and how organizations react to the disgrace of their industry peers remains understudied, despite its importance.

Our study attempts to fill this gap by developing a theory and providing empirical evidence on how organizations react to vicarious public disgracing. Building on the legitimacy and category theories, we assume that since stakeholders evaluate organizations belonging to the same category in a similar manner [14,15], the legitimacy threat originating from public disgrace diffuses across organizations within the same industry. This assumption entails that as vicarious public disgracing increases, focal firms take remedial actions in response to the potential legitimacy threats, regardless of their innocence. We particularly focus on the improvement of corporate social performance (CSP) as a remedial action 
because it is considered to be effective in creating legitimacy and a favorable organizational impression [16]. To empirically test our predictions, we analyze 710 Japanese firms that their peers are blacklisted by the government for labor law delinquency, between 2016 and 2019. The findings support our predictions and reveal that organizational CSP increases with increased vicarious public disgracing in the same industry, especially in firms with a poor CSP record.

Our study makes significant contributions to the literature. Although prior studies suggest diverse factors that motivate firms to enhance their CSP $[17,18]$, to the best of our knowledge, they do not address the relation between vicarious public disgrace and CSP. Hence, the results of this study provide a new antecedent to CSP improvement and enrich the existing literature. Further, we extend the legitimacy theory by displaying the influence of potential public disgrace spillover. This is a clear distinction from other studies that mainly focus on testing the legitimacy losses of the organizations directly suffering public disgrace $[12,13]$. Finally, our results provide practical implications for policymakers by suggesting ways to improve CSP, and for organizational managers by highlighting a possible source of legitimacy losses.

\section{Literature Review}

\subsection{Public Disgrace}

Public disgrace has been explored in the diverse research areas of social sciences, such as psychology, sociology, and business [19,20]. In the organizational context, public disgrace implies organizational scandals or incidents where organizations are publicly criticized because of their illegitimate behaviors, such as financial frauds or rule violations $[19,21]$. As these events significantly threaten organizational survival and affect their short- and long-term performances [21,22], scholars consider public disgrace a critical issue.

The legitimacy theory provides a solid backbone for understanding the impact of public disgrace on organizations. According to this theory, organizational survival and performance are functions of legitimacy acquisition $[10,11]$. Organizational survival is guaranteed when firms are able to successfully project their activities as socially desirable and legitimate [23]. Further, when a firm's illegitimate behavior or the violation of its social expectations is publicized, its legitimacy is negatively affected and its survival is put at risk $[8,9]$.

The legitimacy theory addresses the adverse consequences of public disgrace based on the notion of stigma, which is a "mark of shame," given by public discourse [24]. When organizational illegitimacy is divulged, and field actors publicly criticize it, organizations are stigmatized as antisocial or harmful entities. Stigma is a critical factor in organizational performance and survival as it creates several disadvantages, such as restricted access to major resources [8], negative reputation [25], and stakeholders' disapproval [26]. Consequently, public disgrace becomes a significant driver of legitimacy losses and, therefore, organizational failure.

\subsection{Diffusions of Public Disgrace}

This study assumes that organizational legitimacy losses following public disgrace diffuse across firms within the same industry. That is, when industry peers are publicly disgraced because of their illegitimate acts, focal organizations, despite being clean, receive sanctions in the form of secondhand negative evaluation by stakeholders.

The category theory provides the theoretical background for this assumption. It suggests stakeholders' perception and evaluation of an organization are driven not only by the organization, but also the category to which they belong. By evaluating organizations based on their categories, stakeholders can simplify the interpretation processes for judging organizations and evaluate them more efficiently [26]. Therefore, scholars have noted that the harmful effects of stigma, represented by a negative reputation or stakeholders' disapproval, can diffuse to other organizations within the same category $[1,15,27]$. 
Organizations in the same industry share many commonalities, for example, in market strategies and technologies, and have similar technological and institutional environments [28]. Due to these commonalities, stakeholders are likely to perceive members from the same industry under a single category and evaluate them in a similar manner [15].

Supporting this argument, several category studies suggest stigma or the negative evaluation by stakeholders tends to be shared within the same industry $[9,27,29]$. For instance, Vergne [26] confirms that organizations engaged in arms sales are affiliated to the stigmatized arms industry and, thus, earn lower social evaluation. Similarly, Roulet [27] states that after the subprime crisis in the late 2000s, all firms within the same financial industry, regardless of their innocence, came under strict scrutiny from stakeholders, and their behaviors were publicly questioned. Min [30] shows that the performance of international airlines significantly declines when their industry peers suffer critical accidents.

\subsection{CSP as a Reaction to Legitimacy Losses}

When organizations face legitimacy threats, the most promising way to protect or recover their legitimacy is by improving their social performance [31]. From the perspective of the legitimacy theory, organizations are likely to engage in corporate social responsibility (CSR) activities and improve CSP to acquire legitimacy [16]. CSR is generally defined as the organizational actions that appear to have a positive social impact, beyond the interests of the firm, to meet stakeholders' expectations [25]. Therefore, organizations attempt to improve CSP to build a reputation for their survival and growth, which helps them earn a good evaluation of their products [32] and in investment stimulation [33].

In particular, given that CSP is an effective tool for legitimacy acquisition [34], organizations actively conduct CSR activities when they suffer an image crisis and need to restore their damaged reputation. For example, McDonnell and King [35] find that organizations tend to engage in active prosocial activities after facing serious boycotts. Other scholars also show that organizational sustainability activities tend to increase after disastrous events [36].

In summary, the legitimacy and category theories suggest that (1) public disgrace results in critical losses to organizational legitimacy; (2) such losses diffuse within the same categories, specifically the same industries, through stigmatization; and (3) organizations observe CSP as a mitigating method against legitimacy threats.

\section{Hypotheses}

\subsection{Effects of Vicarious Public Disgrace}

Based on the theoretical arguments presented in Section 2, we suggest that when many industry peers experience public disgrace due to illegitimate events (i.e., when vicarious public disgrace occurs), organizations take certain strategic reactions because of the potential diffusion of stigma within the industry boundaries, despite their innocence. Specifically, they improve CSP so that their socially responsible images can be appealed to reinstate and guarantee their legitimacy.

This tendency arises because of the heightened attention to and stakeholders' scrutiny of the industries. As previously stated, stakeholders evaluate organizations within the same industries $[9,29]$. When several industry members experience public disgrace due to illegitimate acts, stakeholders may question the activities of all industry members. Consequently, industry members, regardless of their innocence, can receive heightened scrutiny from the stakeholders.

There are several real-world examples to support this prediction. In 2008, when approximately 300,000 babies fell sick in China after consuming the contaminated milk powder produced by the Sanlu Group, a domestic dairy firm, stakeholders not only criticized the company publicly, but also raised concerns about the sustainability of the Chinese dairy industry [37]. As a result, the Chinese government conducted reliability tests for most 
industry members and strengthened their product safety standards [38]. The aforementioned oil spill accident by Exxon Valdez showed a similar tendency. After the company spilled 10.8 million US gallons of crude oil, all other innocent tankers were criticized in the global societies. Consequently, stakeholders viewed all less-equipped tankers as a threat to the environment. This resulted in the establishment of wider regulations and stricter standards for the entire shipping industry, including the revision of the spill prevention plans [39].

These theoretical arguments and real-world examples show that organizations are significantly influenced by vicarious public disgrace because of increased stakeholders attention and restrictions on the industries to which the disgraced firms belong. As outlined previously, since CSP tends to be applied to address these situations, we propose the following hypothesis:

Hypothesis 1 (H1). The focal organization's CSP increases with increased vicarious public disgracing (i.e., more industry peers experiencing public disgrace).

\subsection{Moderating Roles of Organizations' Prior CSP}

Category studies suggest that not all organizations in the same category are evaluated equally by stakeholders [26] because of stakeholders' bounded attention abilities [40]. For instance, Vergne [26] claims that firms associated with stigmatized categories are more vulnerable to negative spillovers when they have a stronger association with such stigmatized attributes. Other scholars also note that in the same category, some organizations are more highlighted than others in terms of their negative attributes, such that they tend to be more vulnerable to the diffusion of public disgrace [9]. This study suggests that organizations' previous CSP may serve as a moderator for the influence of vicarious public disgrace as follows.

First, given that illegitimacy is the source of vicarious public disgrace, stakeholders' attention to and monitoring of industry members after a vicarious public disgrace is concentrated more on socially less-legitimated organizations (i.e., organizations with a poorer previous CSP). As Chatterii and Toffel [12] argue, due to their significant association with illegitimacy and irresponsibility, organizations with poorer previous CSP are more likely to come under scrutiny, prompting managerial actions to be undertaken to address stakeholders' concerns.

Second, according to the feedback literature, poorer organizational performance causes significant and sensitive reactions that subsequently improve future performance [41] because negative feedback highlights the need for revising the current state of their performance. Hence, when observing the public disgrace of industry peers, organizations with poorer previous CSP might be more stimulated as they could easily be the subject of such public punishment in the future. This motivates them to appeal to their socially responsible aspects.

Thus, organizations with poorer previous CSP are more sensitive to vicarious public disgrace because of the greater concern of receiving potential scrutiny from stakeholders and the need for reactions to negative feedback. Thus, we propose the following:

Hypothesis 2 (H2). A focal organization's poorer previous CSP strengthens the positive influence of vicarious public disgrace on its CSP.

\section{Research Methodology}

\subsection{Empirical Context and Sample}

To define public disgrace, this study used the context of blacklisted companies publicized by the Japanese government. Since the late 1990s, owing to a serious labor shortage [42], Japanese workers have been forced to work for longer hours. Such excruciating working conditions have led to an increase in deaths from overwork, called karoshi [43]. Japanese workers use the term "black company" to refer to such exploitative firms. This 
term was among the top 10 catchwords in the annual Buzzwords Awards-a list of most frequently discussed words in Japan [44]. Thus, the term "black company" has been stigmatized to represent antisocial firms in this context. To respond to these social concerns about black companies, the Japanese government started disclosing a monthly list of exploitative firms, which violated the major labor laws, on its website since 2016. Despite the lack of a formal definition, the firms blacklisted by the government are commonly referred to as "black companies" [45]. Stakeholders have also introduced the term "black industries" to refer to the industries that include many "black companies."

This context is appropriate for testing our hypotheses. Public shaming by the government creates a nationwide legitimacy loss for organizations. Given its powerful and wide scope of influence, the public disclosure of blacklisted firms matches the theoretical definition of public disgrace and reflects the assumption of stigma diffusion from public disgrace. We obtained data on the annual blacklisted firms from the webpage of the Countermeasure Guide for Black Companies (https:/ / black-company.me/black-list/ (accessed on 9 November 2021)).

The sample for this study was drawn from an annual survey on CSR conducted by Toyo Keizai Inc. between 2016 and 2019. The Toyo Keizai CSR data have been used worldwide in empirical studies based on Japanese contexts [46-48], as it provides the largest pool of information about Japanese firms' CSR and CSP activities $[49,50]$.

We focus mainly on the organizational reactions to public disgrace experienced by industry peers, rather than their own. Thus, our sample in the main analysis excluded the firms that directly experienced public disgrace; however, such firms were analyzed in the additional analysis section to gain further insights. The final sample includes 710 obtained firms from 21 industries with 1881 observations during the sample period, after omitting the missing values.

\subsection{Variables}

\subsubsection{Dependent Variable $(t+1)$}

Firms' CSP, the dependent variable, was calculated based on the CSP scores provided by the Toyo Keizai CSR data. Using more than 150 question items, these scores were calculated via five dimensions: Human resources use, environment, corporate governance, sociality, and financial evaluation about stability. The data source provided scores for each dimension as well as the total score (out of 600 points). To define CSP, we used two indicators: The CSP score for the dimension of human resources use (CSP score for HR) and the total CSP score.

The CSP score for HR appears to define CSP appropriately in our empirical context because the definition of vicarious public disgrace (blacklisted peers) is directly relevant to the use of human resources. Nevertheless, we consider the total CSP score as more appropriate in testing our hypothesis for two reasons. First, as the focal firms did not experience any public disgrace in our sample, they might already have satisfactory CSP scores for HR. Second, stakeholders are likely to pay more attention to the total CSP score, while the formal CSP rankings are created based on the total score. Hence, to improve organizational impression through CSR activities, the sample firms might attempt to improve the overall CSP score.

\subsubsection{Independent Variable ( $\mathrm{t}$ )}

To define the independent variable-vicarious public disgrace-we counted the annual number of industry peers who experienced public disgrace, that is, the peers who were publicly blacklisted by the Japanese government due to labor law delinquency. Figure 1 shows the average number of blacklisted firms throughout the sample period by industry. Many blacklisted firms were pooled from the construction industry, which has often been criticized for its harsh working conditions in Japan [51]. 


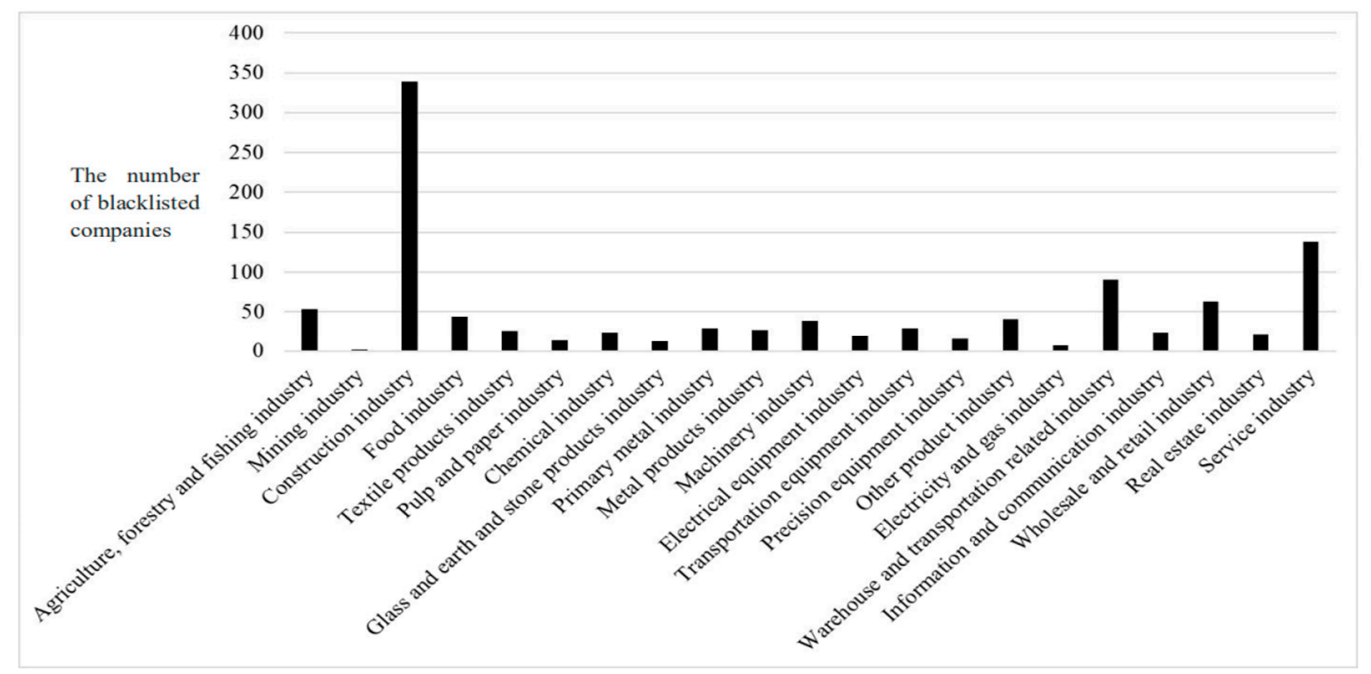

Figure 1. Total number of blacklisted companies by industries.

\subsubsection{Moderator Variable ( $\mathrm{t})$}

To determine the previous CSP, we used the firms' CSP ranking in the previous year (previous CSP ranking). We used the ranking, rather than the scores, in the main analysis, because rankings are more effective in highlighting the relative status of organizations with regard to CSP. Log-transformation was applied to this variable because higher rankings (i.e., lower values) might be more influential owing to their visibility.

\subsubsection{Control Variables ( $\mathrm{t}$ )}

We considered several control variables to respond to alternative explanations. At the organizational level, we controlled for firm age and return on assets (ROA) because older or high-performing organizations have more resources for CSR engagement and may also be more sensitive to legitimacy losses. Waddock and Graves found that the firms with higher financial performance tend to attain a higher CSP [17].

The social network literature cites the influences of interorganizational networks on the diffusion of CSR activities or stigma among organizations [52]. Particularly, managers may strongly react to the public disgrace of other firms with whom they collaborate. To reflect on these network influences, we included a dummy variable that indicates the same consortium memberships of the focal organization with the industry peers who experienced public disgrace.

Several CSR studies emphasize the significant influence of the upper echelons on CSR. In particular, many of these studies explore the roles of women and outside directors in improving CSP [53,54]. According to these studies, with increases in the number of women and outside directors in the board, organizations are likely to engage in CSR activities more actively. To reflect on the influences of the upper echelons, we included the ratios of female and outside directors on the board.

Finally, at the industry level, we controlled for the log-transformed industry GDP (billions) because the environmental economic conditions can influence firms' decisions about CSR activities [55]. We also included the total number of peers, using the total number of sample firms in the industry for focal firms, to reflect on the potentially biased results from the different number of peers across industries in our sample. A smaller number of firms in the industry might highlight the firms that experienced public disgrace in the industry. This might cause strong organizational reactions to vicarious public disgrace within the industry. All variables are summarized in Appendix A.

\subsection{Model Estimation}

The dependent variable of this study is characterized by numerical and continuous values-the annual CSP scores of each firm. Therefore, linear regression is appropriate 
for testing the hypotheses. We employed an ordinary least-squares estimator according to prior studies on CSP $[55,56]$. Due to the potential correlation of residuals for a given firm, the fixed-effect models with clustered standard errors are appropriate for our hypothesis testing. By applying the fixed-effect models, we controlled for the time-invariant and unobservable firm characteristics, such as their inherent task characteristics or organizational culture, which might generate biased results. Results from the Hausman test [57] further confirmed the appropriate choice of the fixed-effect models. We also applied yearand industry-fixed effects to account for the year- and industry-specific influences. These controls are necessary because some industries might have a higher chance of having a larger number of blacklisted firms by the virtue of their job characteristics. For the analysis, the "plm Package" in R software was used [58].

\section{Results}

Table 1 displays the descriptive statistics for each variable used in the analysis. Table 2 shows the correlations between the variables. To check for multicollinearity, we investigated the variance inflation factors (VIFs). The individual VIFs ranged from 1.013 to 2.295, and the average VIF was 1.382. As all the VIFs are below the accepted value of 10, multicollinearity is unlikely to bias our analysis results.

Table 1. Descriptive statistics $(\mathrm{N}=1881)$.

\begin{tabular}{|c|c|c|c|c|c|c|}
\hline & Variables & Mean & SD & Min & Median & Max \\
\hline 1 & $\operatorname{CSP}(t+1)$ & 444.800 & 66.987 & 312.400 & 447.500 & 575.700 \\
\hline 2 & CSP for HR $(t+1)$ & 68.810 & 17.704 & 20 & 72.700 & 100 \\
\hline 3 & Vicarious public disgrace & 20.210 & 32.780 & 0 & 10 & 183 \\
\hline 4 & Ln (previous CSP ranking) & 5.564 & 0.980 & 0.693 & 5.867 & 6.677 \\
\hline 5 & Firm age & 67.660 & 24.919 & 4 & 69 & 148 \\
\hline 6 & Network influences & 0.098 & 0.302 & 0 & 0 & 1 \\
\hline 7 & ROA & 4.616 & 3.106 & 0.030 & 4.070 & 36.710 \\
\hline 8 & Ratio of female directors & 0.056 & 0.071 & 0 & 0.048 & 0.600 \\
\hline 9 & Ratio of outside directors & 0.227 & 0.103 & 0 & 0.200 & 0.833 \\
\hline 10 & Ln (industry GDP) & 9.774 & 0.953 & 5.642 & 9.685 & 11.266 \\
\hline 11 & Total number of peers & 55.400 & 30.924 & 1 & 43 & 105 \\
\hline
\end{tabular}

Note: Ln indicates log-transformed values; the maximum value of total number of peers is smaller than that of vicarious public disgrace because the former is counted within our sample, whereas the latter reflects the annual total number of backlisted firms among all Japanese firms.

Table 2. Correlation matrix.

\begin{tabular}{|c|c|c|c|c|c|c|c|c|c|c|c|}
\hline & Variables & 1 & 2 & 3 & 4 & 5 & 6 & 7 & 8 & 9 & 10 \\
\hline 1 & $\operatorname{CSP}(t+1)$ & & & & & & & & & & \\
\hline 2 & CSP for HR $(t+1)$ & $0.881^{* * *}$ & & & & & & & & & \\
\hline 3 & Vicarious public disgrace & $-0.050 *$ & $-0.062^{* *}$ & & & & & & & & \\
\hline 4 & Ln (previous CSP ranking) & $-0.849^{* * *}$ & $-0.695^{* * *}$ & $0.093^{* * *}$ & & & & & & & \\
\hline 5 & Firm age & $0.203^{* * *}$ & $0.139 * * *$ & $-0.075^{* *}$ & $-0.187^{* * *}$ & & & & & & \\
\hline 6 & Network influences & $0.066^{* *}$ & 0.031 & $0.173^{* * *}$ & $-0.048 *$ & $0.148^{* * *}$ & & & & & \\
\hline 7 & ROA & $0.061^{* *}$ & $0.058^{*}$ & 0.025 & $-0.041^{\dagger}$ & $-0.132 * * *$ & -0.009 & & & & \\
\hline 8 & Ratio of female directors & $0.261^{* * *}$ & $0.342 * * *$ & 0.012 & $-0.233^{* * *}$ & $-0.069 * *$ & -0.023 & $0.083^{* * *}$ & & & \\
\hline 9 & Ratio of outside directors & $0.056 *$ & $0.090^{* * *}$ & $-0.068 * *$ & $-0.040^{\dagger}$ & $-0.043^{\dagger}$ & 0.013 & $0.053 *$ & $0.255^{* * *}$ & & \\
\hline 10 & Ln (industry GDP) & $-0.178^{* * *}$ & $-0.115^{* * *}$ & $0.333^{* * *}$ & $0.166^{* * *}$ & $-0.281^{* * *}$ & -0.018 & 0.006 & $0.075^{* *}$ & -0.014 & \\
\hline 11 & Total number of peers & 0.017 & 0.016 & $-0.122 * * *$ & -0.027 & -0.002 & -0.032 & $0.126^{* * *}$ & $0.054 *$ & $0.093 *$ & $0.174^{* * *}$ \\
\hline
\end{tabular}

Note: Ln indicates log-transformed values. ${ }^{+} p<0.10 ;{ }^{*} p<0.05 ;{ }^{* *} p<0.01 ; * * * 0.001$.

\subsection{Main Results}

Table 3 presents the analysis results for $\mathrm{H} 1$ and $\mathrm{H} 2$. Models 1-3 show the results based on the total CSP scores, whereas Models 4-6 represent those based on the CSP scores for HR. Model 1 is the baseline model, which includes only the control variables. As predicted, firms' lower previous CSP rankings (i.e., larger previous ranking values) ( $\beta=0.038, p=$ 
$0.052)$ and firm age $(\beta=2.325, p<0.001)$ are positively related to CSP. Underperforming firms in CSP are more likely to face legitimacy threats. Older firms are more recognized in society and, thus, display higher sensitivity to social responsibility. Intriguingly, Model 1 also shows an unexpected result that the proportion of female directors is negatively associated with CSP $(\beta=-0.019, p=0.064)$. This finding conflicts with the previous results that female directors facilitate CSR activities [54]. However, these results are justifiable in the Japanese context. Given that hiring female directors is considered a major CSR activity in itself, in the Japanese context [59], firms that hire several female directors may neglect other overall CSR activities.

Table 3. Regression results of the effects of vicarious public disgrace on CSP ( $\mathrm{N}=1881)$.

\begin{tabular}{|c|c|c|c|c|c|c|}
\hline \multirow{2}{*}{ Variables } & \multicolumn{3}{|c|}{ Total CSP Scores } & \multicolumn{3}{|c|}{ CSP Scores for HR } \\
\hline & Model 1 & Model 2 & Model 3 & Model 4 & Model 5 & Model 6 \\
\hline \multirow[t]{2}{*}{ Vicarious public disgrace } & & $0.024^{* * *}$ & $-0.126^{* * *}$ & & $0.032 *$ & -0.097 \\
\hline & & $(0.008)$ & $(0.038)$ & & $(0.014)$ & $(0.070)$ \\
\hline Vicarious public disgrace $x$ & & & $0.154^{* * *}$ & & & 0.131 \\
\hline Ln (previous CSP ranking) & & & $(0.038)$ & & & $(0.070)$ \\
\hline \multirow[t]{2}{*}{ Ln (previous CSP ranking) } & $0.038^{+}$ & $0.042 *$ & 0.025 & -0.005 & -0.000 & -0.014 \\
\hline & $(0.020)$ & $(0.020)$ & $(0.020)$ & $(0.036)$ & $(0.036)$ & $(0.037)$ \\
\hline \multirow[t]{2}{*}{ Firm age } & $2.325^{* * *}$ & $2.128^{* * *}$ & $2.130^{* * *}$ & $1.566^{* * *}$ & $1.307^{* * *}$ & $1.309^{* * *}$ \\
\hline & $(0.161)$ & $(0.172)$ & $(0.171)$ & $(0.296)$ & $(0.317)$ & $(0.316)$ \\
\hline \multirow[t]{2}{*}{ Network influences } & -0.002 & -0.003 & -0.003 & 0.000 & -0.002 & -0.001 \\
\hline & $(0.005)$ & $(0.005)$ & $(0.005)$ & $(0.008)$ & $(0.009)$ & $(0.008)$ \\
\hline \multirow[t]{2}{*}{ ROA } & 0.010 & 0.010 & 0.012 & 0.014 & 0.015 & 0.016 \\
\hline & $(0.009)$ & $(0.009)$ & $(0.009)$ & $(0.017)$ & $(0.017)$ & $(0.017)$ \\
\hline \multirow[t]{2}{*}{ Ratio of female directors } & $-0.019^{\dagger}$ & $-0.018^{\dagger}$ & -0.015 & -0.015 & -0.014 & -0.011 \\
\hline & $(0.010)$ & $(0.010)$ & $(0.010)$ & $(0.019)$ & $(0.019)$ & $(0.019)$ \\
\hline \multirow[t]{2}{*}{ Ratio of outside directors } & 0.006 & 0.007 & 0.007 & 0.002 & 0.004 & 0.004 \\
\hline & $(0.012)$ & $(0.012)$ & $(0.012)$ & $(0.022)$ & $(0.022)$ & $(0.022)$ \\
\hline \multirow[t]{2}{*}{ Ln (industry GDP) } & -0.121 & -0.198 & -0.204 & 0.072 & -0.030 & -0.035 \\
\hline & $(0.171)$ & $(0.172)$ & $(0.171)$ & $(0.315)$ & $(0.318)$ & $(0.317)$ \\
\hline \multirow[t]{2}{*}{ Total number of peers } & 0.048 & 0.032 & 0.030 & 0.096 & 0.075 & 0.073 \\
\hline & $(0.054)$ & $(0.055)$ & $(0.054)$ & $(0.100)$ & $(0.100)$ & $(0.100)$ \\
\hline Firm fixed effects & Yes & Yes & Yes & Yes & Yes & Yes \\
\hline Industry fixed effects & Yes & Yes & Yes & Yes & Yes & Yes \\
\hline Year fixed effects & Yes & Yes & Yes & Yes & Yes & Yes \\
\hline Log likelihood & 1508.203 & 1516.502 & 1529.86 & 363.712 & 367.929 & 370.793 \\
\hline $\mathrm{R}^{2}$ & 0.309 & 0.315 & 0.324 & 0.073 & 0.077 & 0.08 \\
\hline F statistic & $57.080^{* * *}$ & $52.802 * * *$ & $50.140^{* * *}$ & $10.121^{* * *}$ & $9.659^{* * *}$ & $9.118^{* * *}$ \\
\hline
\end{tabular}

Note: All the independent and control variables are one-year lagged; all variables are standardized; standard errors are in parentheses; Ln indicates log-transformed values. ${ }^{\dagger} p<0.10$; $^{*} p<0.05 ;{ }^{* *} p<0.01{ }^{* * *} p<0.001$.

Model 2 shows the effect of vicarious public disgrace on focal firms' total CSP. The coefficient of vicarious public disgrace shows a positive and statistically significant value $(\beta=0.024, p<0.001)$. This implies that with increased vicarious public disgrace, organizations make more effort to improve CSP. The result strongly supports H1. Model 3 of Table 3 tests the moderating effects of the previous CSP ranking. The coefficient of 
the interaction term between vicarious public disgrace and the previous CSP ranking is positive and significant $(\beta=0.154, p<0.001)$. Thus, as predicted in $\mathrm{H} 2$, CSR improvement following vicarious public disgrace tends to be higher for organizations with lower previous CSP rankings (i.e., larger previous ranking values). The results using CSP scores for HR also show a similar tendency, as presented in Models 5-6 (H1: $\beta=0.032, p=0.023$; $\mathrm{H} 2: \beta=0.131, p=0.061)$. The lower statistical significance of these results compared with the results based on the total CSP score might imply that the total score is a more appropriate measure for our hypotheses, as mentioned previously.

To gain further insight, we plotted the results of $\mathrm{H} 2$ in Figure 2. In this figure, the horizontal axis represents the degree of vicarious public disgrace, and the longitudinal axis represents CSP. The bold line shows the results for the organizations with a lower previous CSP ranking (larger values, Mean + 1SD), whereas the dotted line indicates those with a higher previous CSP ranking (smaller values, Mean - 1SD). As shown in the figure, the positive effects of vicarious public disgrace on CSP are more significant when organizations perform poorly in terms of CSR activities.

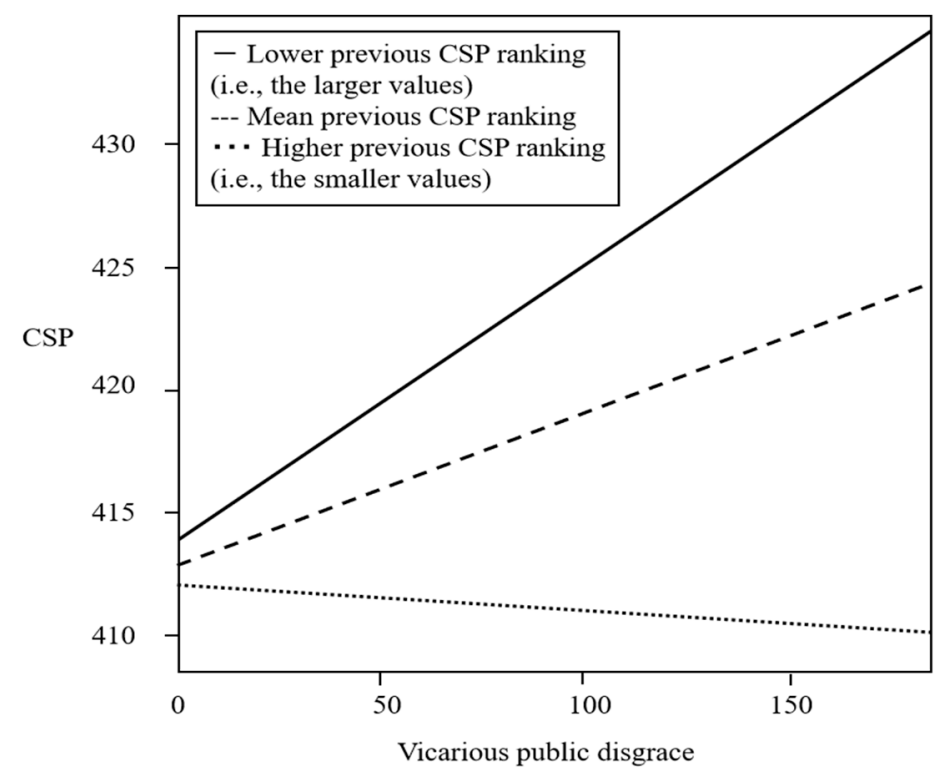

Figure 2. Moderating effect of previous CSP ranking.

\subsection{Robustness Analyses}

To check the robustness of the results above, we conducted several analyses and showed the major results in Table 4. We conducted all the analyses for robustness checks by using two dependent variables: The total CSP score and the CSP scores for HR. As both the indicators showed similar tendencies, we only represent those results based on the total CSP score. 
Table 4. Regression results of the additional analyses $(\mathrm{N}=1881)$.

\begin{tabular}{|c|c|c|c|c|c|c|c|}
\hline Variables & Model 1 & Model 2 & Model 3 & Model 4 & Model 5 & Model 6 & Model 7 \\
\hline \multirow[t]{2}{*}{ Vicarious public disgrace } & & & $0.022 *$ & $-0.111 *$ & $0.156^{* * *}$ & $0.065^{* * *}$ & $-0.092^{+}$ \\
\hline & & & $(0.009)$ & $(0.047)$ & $(0.041)$ & $(0.008)$ & $(0.048)$ \\
\hline Vicarious public disgrace $\times$ & & & & $0.137 * *$ & & & $0.161^{* * *}$ \\
\hline Ln (previous CSP ranking) & & & & $(0.047)$ & & & $(0.049)$ \\
\hline \multirow[t]{2}{*}{ W (vicarious public disgrace) } & $0.026^{* * *}$ & $-0.169 * * *$ & & & & & \\
\hline & $(0.007)$ & $(0.041)$ & & & & & \\
\hline $\mathrm{W}$ (vicarious public disgrace) $\times$ & & $0.198^{* * *}$ & & & & & \\
\hline Ln (previous CSP ranking) & & $(0.042)$ & & & & & \\
\hline \multirow[t]{2}{*}{ Ln (previous CSP ranking) } & $0.043 *$ & 0.026 & -0.011 & -0.026 & & $-0.422 * * *$ & $-0.438^{* * *}$ \\
\hline & $(0.020)$ & $(0.020)$ & $(0.024)$ & $(0.025)$ & & $(0.018)$ & $(0.019)$ \\
\hline \multirow[t]{2}{*}{ Previous CSP } & & & & & $0.231^{* * *}$ & & \\
\hline & & & & & $(0.029)$ & & \\
\hline Vicarious public disgrace $\times$ & & & & & $-0.135^{* * *}$ & & \\
\hline Previous CSP & & & & & $(0.040)$ & & \\
\hline \multirow[t]{2}{*}{ Constant } & & & & & & $-0.059 *$ & $-0.059 *$ \\
\hline & & & & & & $(0.024)$ & $(0.024)$ \\
\hline Other control variables & Yes & Yes & Yes & Yes & Yes & Yes & Yes \\
\hline Firm fixed effects & Yes & Yes & Yes & Yes & Yes & No & No \\
\hline Industry fixed effects & Yes & Yes & Yes & Yes & Yes & No & No \\
\hline Year fixed effects & Yes & Yes & Yes & Yes & Yes & No & No \\
\hline Log likelihood & 1518.781 & 1537.202 & 1114.604 & 1121.475 & 1565.554 & 532.122 & 536.219 \\
\hline$R^{2}$ & 0.316 & 0.330 & 0.105 & 0.112 & 0.349 & 0.330 & 0.335 \\
\hline F statistic & $53.209^{* * *}$ & $51.352^{* * *}$ & $13.495^{* * *}$ & $13.113^{* * *}$ & $56.120^{* * *}$ & $906.050 * * *$ & $924.220 * * *$ \\
\hline
\end{tabular}

Note: All the independent and control variables are one-year lagged; all variables are standardized; standard errors are in parentheses; Ln indicates log-transformed values; $\mathrm{W}$ indicates weighed values. ${ }^{+} p<0.10 ;{ }^{*} p<0.05 ;{ }^{* *} p<0.01 ;{ }^{* * *} p<0.001$.

First, this study assumes that a linear relationship exists between vicarious public disgrace and CSP score. To disprove the potential U-shaped or inverted U-shaped relationship, we conducted a test using squared vicarious public disgrace. Although we do not present the results, we found insignificant impacts of the non-linear relationship from this robustness check.

Second, the effects of vicarious public disgrace may be dependent on the relative size of the industry. In smaller industries, a large number of blacklisted peers can indicate a more significant stigma at the industry level. Hence, it might have a stronger influence on the reaction of focal firms. Following this chain of thought, we calculated the weights by using the ratio of the number of firms in the focal industry to the total number of firms across industries. Then, we created a weighted vicarious public disgrace by dividing the number of blacklisted industry peers by these weights. Through this measurement, firms in the agricultural, forestry, and fishing sectors showed the highest mean of vicarious public disgrace, rather than the construction industry. As shown in Models 1 and 2, the analysis results using the weighted variables replicate the original analysis results $(\mathrm{H} 1: \beta=0.026$, $p<0.001 ; \mathrm{H} 2: \beta=0.198, p<0.001)$ and strongly support our hypotheses.

Third, the original total CSP scores were calculated based on the five dimensions or a single dimension of human resources use. For the total CSP score, because financial evaluation is less relevant to social performance, the final score was recalculated based on only four dimensions: Human resource use, environment, corporate governance, and sociality. Thus, financial evaluation was removed from the total score. As shown in Models 3 and 4 , the analysis results replicate the original results $(\mathrm{H} 1: \beta=0.022, p=0.017$; $\mathrm{H} 2: \beta=0.137, p=0.004)$. 
Fourth, to test the moderating effect in $\mathrm{H} 2$, we used the scores of the previous CSP, rather than the log-transformation of the previous CSP ranking. The result is shown in Model 5 (H2: $\beta=-0.135, p<0.001$ ). It suggests that firms with a low previous total CSP score are likely to perform better in CSP, thus supporting the hypothesis.

Fifth, we applied random effects throughout the models rather than the previous fixed effects. The analysis results, as shown in Models 6 and 7 (H1: $\beta=0.065, p<0.001$; H2: $\beta=0.161, p<0.001)$, support the hypotheses.

\subsection{Additional Analyses}

Our major interest in this study was to examine whether innocent firms react to their industry peers' public disgrace by improving their own CSP. Hence, in the main analysis, we excluded the blacklisted firms from our sample. To gain further insights, this section incorporated a dummy variable (firsthand public disgrace) that takes the value of 1 for blacklisted firms, and 0 otherwise. Then, we tested their influences on the CSP scores, which are represented in Table 5.

Table 5. Regression results of the additional analyses $(\mathrm{N}=1894)$.

\begin{tabular}{ccc}
\hline Variables & Model 1 & Model 2 \\
\hline Vicarious public disgrace & $0.024^{* *}$ & $0.023^{* *}$ \\
\hline Firsthand public disgrace & $(0.007)$ & $(0.007)$ \\
\hline ROA $\times$ & $-0.008^{\dagger}$ & $-0.032^{* *}$ \\
\hline Firsthand public disgrace & $(0.004)$ & $(0.012)$ \\
\hline ROA & & $0.024^{*}$ \\
\hline Other control variables & 0.011 & $(0.011)$ \\
\hline Firm fixed effects & $(0.009)$ & 0.01 \\
\hline Industry fixed effects & Yes & $(0.009)$ \\
\hline Year fixed effects & Yes & Yes \\
\hline Log likelihood & Yes & Yes \\
\hline $\mathrm{R}^{2}$ & Yes & Yes \\
\hline F statistic & 1519.104 & 1522.799 \\
\hline
\end{tabular}

Note: All the independent and control variables are one-year lagged; all variables are standardized; standard errors are in parentheses; Ln indicates log-transformed values. ${ }^{+} p<0.10 ;{ }^{*} p<0.05 ;{ }^{* *} p<0.01$; ${ }^{* * *} p<0.001$.

First, controlling the effect of the firsthand public disgrace, we obtained the consistently significant impacts of vicarious public disgrace in Model $1(\beta=0.024, p=0.001)$. However, unexpectedly, the firsthand public disgrace shows a negative and significant coefficient in Model 1 ( $\beta=-0.008 ; p=0.055$ ). This result contradicts our intuition as well as the previous common knowledge that public disgrace triggers the involvement of firms in socially responsible activities as a means of recovering legitimacy [12]. The results also provide substantial implications for the existence of potential bounded effects of firsthand public disgrace on CSR enhancement.

To elaborate on these unexpected results surrounding the first public disgrace, the second step was to explore the potential moderators for the negative relationship between firsthand public disgrace and CSP. Particularly, we raised the potential moderating role of organizational financial performance for two reasons [17]. First, organizations with lower financial performance might be less sensitive to legitimacy losses owing to public disgrace because of their low popularity. Second, such organizations might have insufficient 
resources to improve CSP, so they might neglect CSR activities even under legitimacy threats. Thus, CSP improvement following public disgrace might be applicable only to firms with higher financial performance.

To test this possibility, we employed the interaction term between firsthand public disgrace and ROA and tested its effect on CSP. As shown in Model 2, its coefficient showed a significantly positive value ( $\beta=0.024, p=0.033)$, supporting our prediction. We also illustrate these effects in Figure 3. This figure suggests that only the firms with higher financial performance (bold line) are likely to improve their CSP following public disgrace.

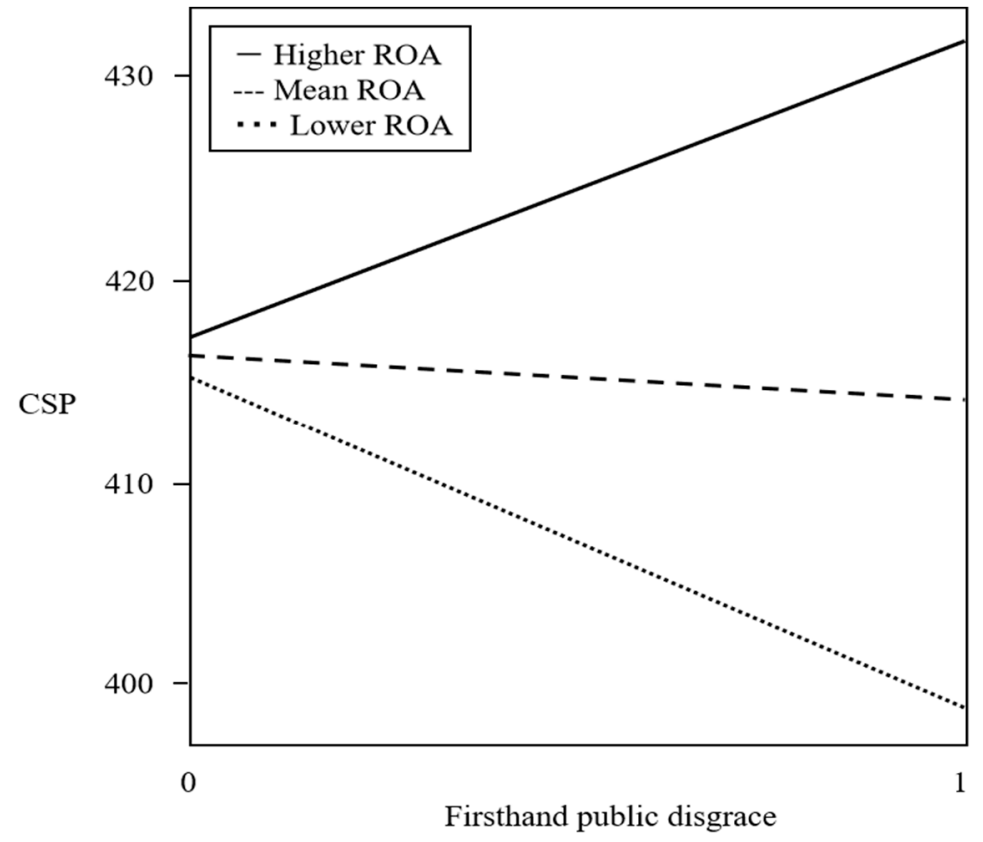

Figure 3. Moderating effect of ROA.

\section{Discussion}

Based on the theories of legitimacy and category, we tested how organizations react to vicarious public disgrace by focusing on their CSP. By analyzing 710 Japanese firms between 2016 and 2019, we found that organizations improve CSP when a large number of their industry peers experience public disgrace on being blacklisted due to labor law delinquency. This tendency was more significant among the firms with poorer previous CSP. These findings highlight the significant effects of vicarious public disgrace on CSP and make several contributions to the relevant literature.

Our results support previous arguments of CSR studies based on the legitimacy theory, by highlighting that organizational engagement in CSR aims to acquire or repair legitimacy [16]. Beyond this adherence to the existing knowledge, the results also provide a new perspective on the diffusion of CSR improvement across organizations. According to our results, it is possible to achieve the field-wide enhancement of CSP by publicly disgracing organizations. Some scholars confirm that CSR activities diffuse across organizations through interorganizational networks $[52,60]$. However, they focus on interorganizational imitation as the mechanism for such CSR diffusion. Our focus on the vicarious legitimacy threats among industry peers is distinct from the previous studies. In addition, our results provide new knowledge on a significant moderator to improve CSP through vicarious public disgrace-the previous CSP. These outcomes introduce and support an intriguing research agenda: The diffusion of CSP improvement under vicarious legitimacy threats.

This study also contributes to the legitimacy theory in three ways. First, previous studies on the legitimacy theory have mainly focused on how organizations react to legitimacy threats caused by their own negative experiences $[8,14]$. Conversely, our theory provides relatively insufficient information about how organizations respond to legitimacy threats 
experienced by industry peers. We focused on this niche area and proved that organizations enhance CSP when their industry peers are disgraced as they fear stigma diffusion within the same category. This broadens the scope of research to test organizational reactions to vicarious legitimacy threats.

Second, our study is also distinguished from existing legitimacy studies concerning the sources of legitimacy threats. The majority of existing studies have relied on the role of mass media as a catalyst for organizational legitimacy threats. For example, Piazza and Perretti [61] find that organizations in the US nuclear power industry bailed as field players when mainstream mass media damaged their field legitimacy. Tang and Tang [62] show that media coverage of firms' illegitimate behaviors leads to restrictions on such firms. Unlike these studies, our study focused on the role of the government as a catalyst for legitimacy threats. Such a focus is indubitable given that the government declares and implements institutional standards that societal members are expected to adhere to. This approach adds a promising but neglected provider of organizational legitimacy threats.

Third, previous legitimacy studies suggest that organizations experiencing public disgrace should make efforts to lessen the stigma attached to them by improving social performance [12]. In particular, Hampel and Tracey [13] suggest a two-step process to absorb the shocks created by stigma: Stigma reduction and appealing for higher social performance. However, in additional analysis, we empirically provide a caveat that these processes may not necessarily yield any results and that the organizations with lower financial performance may not react to public disgrace (see Figure 3). These results imply that certain boundary conditions may exist that promote organizational social performance in the face of public disgrace and that such conditions are closely relevant to organizational financial performance. Thus, we provide the potential conditional effects of legitimacy threats on organizational social performance.

Our study has several practical implications for policymakers and organizational managers. First, policymakers attempt to enhance the social responsibilities of firms and restrict their illegitimate behaviors by using several costly policies or punishments. In this study, we show that public disgrace can be an effective tool and can be used to address several societal issues, such as financial frauds and misconducts in the academia or education sector, and even in the corporate setting. Second, through the additional analysis, we prove that only financially high-performing organizations react sensitively to their own public disgrace (see Model 2 in Table 5). Therefore, policymakers must realize that public disgrace may not motivate financially underperforming organizations to improve social performance. Finally, organizational managers should be quick to identify the implied cues that might harm their legitimacy and make efforts to respond to the potential negative spillovers in the industry. This is especially true for the industries that include several publicly disgraced organizations. Moreover, given that industry members are sensitive to their peers' public disgrace, organizational managers may consider making a collective effort to improve the industry's image.

Our study also has several limitations. First, the Japanese context provides a useful empirical setting to test our hypotheses because, culturally speaking, public shaming is a highly sensitive matter in Japan [63]. This specific context, therefore, may lead to the bounded generalizability of our findings. Particularly, the notion of public disgrace has long been tested in diverse research contexts across several countries [19,21,64]. However, their varying impacts depending on several international contexts have remained untested. In this connection, future research will be beneficial if it can explore whether and how the impacts of vicarious public disgrace differ, depending on the national cultures. For example, according to Hofstede's cultural dimensions, western countries tend to have low power distance and short-term orientation [65]. Under these cultural environments, companies might be less sensitive to the legitimacy threats caused by the government or less likely to engage in CSR as a response to legitimacy threats.

Second, our sample might have excluded highly illegitimate firms as they did not respond to the survey. This translates to limited variances in social performance among 
sample firms. Although this problem could be common to similar studies and was even effective in testing our hypotheses on how innocent organizations react to vicarious public disgrace, it limits further intriguing tests on how organizations react differently to their own disgrace and vicarious public disgrace or a combination of both. Further studies can focus on these issues to extend the existing knowledge on organizational reactions to public disgrace.

Third, to define categories, we focused only on industry boundaries. However, the organizational perception of categories may also include other dimensions, such as geographical locations or collaborative networks [30]. Although we controlled for network influences in our tests, future studies can employ these diverse perceived categories and generate more information on whether and how organizations react differently to the vicarious public disgrace depending on diverse sources.

Despite several limitations, the theory and empirical findings of this study provide substantial knowledge about organizational responses to vicarious public disgrace and extend the existing literature and theories. The results of this study also provide practical implications for policymakers to enhance organizational CSP as well as for organizational managers to address legitimacy threats. We hope that the approach and findings of this study will offer critical perspectives on current CSR studies and contribute to organizations ${ }^{\prime}$ focus on sustainability issues.

Author Contributions: Conceptualization, R.L. and J.M.; Data curation, R.L.; Formal analysis, R.L.; Funding acquisition, J.M.; Investigation, R.L.; Supervision, J.M.; Writing-original draft, R.L. and J.M.; Writing-review \& editing, R.L. and J.M. All authors have read and agreed to the published version of the manuscript.

Funding: This research was supported by the Murata Science Foundation.

Institutional Review Board Statement: Not applicable.

Informed Consent Statement: Not applicable.

Data Availability Statement: Not available.

Conflicts of Interest: The authors declare no conflict of interest.

\section{Appendix A}

Table A1. Summary of the variables.

\begin{tabular}{|c|c|c|c|}
\hline \multicolumn{2}{|c|}{ Variables } & \multirow[b]{2}{*}{$\begin{array}{c}\text { Descriptions } \\
\text { The total CSR scores (out of } 600 \text { points) } \\
\text { based on more than } 150 \text { question items } \\
\text { (153 items in 2016, } 156 \text { items in } 2017 \text { and } \\
\text { 2018, and 158 items in 2019) in the } \\
\text { dimensions of human resources use } \\
\text { (100 points), environment (100 points), } \\
\text { corporate governance and sociality } \\
\text { (100 points), and financial evaluation, } \\
\text { including three dimensions of } \\
\text { profitability, namely, safety and scale } \\
\text { (300 points) }\end{array}$} & Sources \\
\hline \multirow[t]{2}{*}{$\begin{array}{l}\text { Dependent variable at time } \\
\qquad t+1\end{array}$} & CSP & & CSR kigyo-hakusyo \\
\hline & CSP for HR & $\begin{array}{l}\text { The CSR scores for the dimensions of } \\
\text { human resources use }\end{array}$ & \\
\hline $\begin{array}{l}\text { Independent variable at } \\
\text { time } t\end{array}$ & Vicarious public disgrace & $\begin{array}{l}\text { Number of the blacklisted industry } \\
\text { peers by the Japanese government }\end{array}$ & $\begin{array}{l}\text { Countermeasure Guide for Black } \\
\text { Companies on https: } \\
\text { / / black-company.me/black-list/ } \\
\text { (accessed on } 9 \text { November 2021) }\end{array}$ \\
\hline Moderator at time $t$ & Ln (previous CSR ranking) & Log-transformed previous CSR ranking & CSR kigyo-hakusyo \\
\hline
\end{tabular}


Table A1. Cont.

\begin{tabular}{|c|c|c|c|}
\hline & Firm age & $\begin{array}{l}\text { The number of years elapsed since } \\
\text { the founded year }\end{array}$ & Each firms' IR information \\
\hline \multirow[t]{6}{*}{ Control variables at time $t$} & Network influences & $\begin{array}{l}\text { A dummy variable taking the value } \\
\text { of one if the focal organization has } \\
\text { the same consortium memberships } \\
\text { with the blacklisted industry peers, } \\
\text { and zero otherwise }\end{array}$ & Nikkei database \\
\hline & $\mathrm{ROA}$ & Return on assets & IR Bank database \\
\hline & Ratio of female directors & $\begin{array}{c}\text { Number of female directors/Total } \\
\text { number of board directors }\end{array}$ & Nikkei database \\
\hline & Ratio of outside directors & $\begin{array}{c}\text { Number of outside directors/Total } \\
\text { number of board directors }\end{array}$ & \\
\hline & Ln (industry GDP) & $\begin{array}{l}\text { Log-transformed industry GDP } \\
\text { (billions) }\end{array}$ & e-Stat database \\
\hline & Total number of peers & $\begin{array}{c}\text { Number of the sample firms in the } \\
\text { industry to which focal } \\
\text { organizations belong }\end{array}$ & CSR kigyo-hakusyo \\
\hline Others at time $t$ & Firsthand public disgrace & $\begin{array}{l}\text { A dummy variable taking the value } \\
\text { of one if the focal organization was } \\
\text { blacklisted in the focal year, and } \\
\text { zero otherwise }\end{array}$ & $\begin{array}{l}\text { Countermeasure Guide for } \\
\text { Black Companies on } \\
\text { https:/ / black-company.me/ } \\
\text { black-list/ (accessed on } 9 \\
\text { November 2021) }\end{array}$ \\
\hline
\end{tabular}

\section{References}

1. Desai, V.M. Mass media and massive failures: Determining organizational efforts to defend field legitimacy following crises. Acad. Manag. J. 2011, 54, 263-278. [CrossRef]

2. Kang, E. Director interlocks and spillover effects of reputational penalties from financial reporting fraud. Acad. Manag. J. 2008, 51, 537-555. [CrossRef]

3. Zavyalova, A.; Pfarrer, M.D.; Reger, R.K.; Shapiro, D.L. Managing the message: The effects of firm actions and industry spillovers on media coverage following wrongdoing. Acad. Manag. J. 2012, 55, 1079-1101. [CrossRef]

4. Lehmann, H.; Wadsworth, J. The impact of Chernobyl on health and labour market performance. J. Health Econ. 2011, 30, 843-857. [CrossRef]

5. Marquiss, K.D.K. The Exxon: Valdez Oil Spill: Industry Response and the Evolution of Environmental Policy; University of Pennsylvania: Philadelphia, PA, USA, 2007.

6. Fujii, T. The Ranking of Black Industries. What Are the 1st to 20th Industries that Should Be Avoided? Available online: https:/ / shukatu-man.hatenablog.com/entry/black-industry-ranking (accessed on 9 November 2021). (In Japanese).

7. Kimura, H. Notice! 25 Industries that Are Not Recommended I The Characteristics of Black Industries and How to Distinguish Them. Available online: https:/ / reashu.com/osusumesinai-gyoukai/ (accessed on 9 November 2021). (In Japanese).

8. Hudson, B.A. Against all odds: A consideration of core-stigmatized organizations. Acad. Manag. Rev. 2008, 33, 252-266. [CrossRef]

9. Devers, C.E.; Dewett, T.; Mishina, Y.; Belsito, C.A. A general theory of organizational stigma. Organ. Sci. 2009, $20,154-171$. [CrossRef]

10. Deephouse, D.L. Does isomorphism legitimate? Acad. Manag. J. 1996, 39, 1024-1039. [CrossRef]

11. Suchman, M.C. Managing legitimacy: Strategic and institutional approaches. Acad. Manag. Rev. 1995, 20, 571-610. [CrossRef]

12. Chatterji, A.K.; Toffel, M.W. How firms respond to being rated. Strateg. Manag. J. 2010, 31, 917-945. [CrossRef]

13. Hampel, C.E.; Tracey, P. Stigmatized in infancy but not for life: The legitimation of the travel agency in Victorian England. Acad. Manag. Proc. 2015, 2015, 13428. [CrossRef]

14. Greve, H.R.; Palmer, D.; Pozner, J.E. Organizations gone wild: The causes, processes, and consequences of organizational misconduct. Acad. Manag. Ann. 2010, 4, 53-107. [CrossRef]

15. Vergne, J.-P.; Wry, T. Categorizing categorization research: Review, integration, and future directions. J. Manag. Stud. 2013, 51, 56-94. [CrossRef]

16. Fatma, M.; Khan, I.; Rahman, Z. Striving for legitimacy through CSR: An exploration of employees responses in controversial industry sector. Soc. Responsib. J. 2019, 15, 924-938. [CrossRef]

17. Waddock, S.A.; Graves, S.B. The corporate social performance-financial performance link. Strateg. Manag. J. 1997, 18, 303-319. [CrossRef] 
18. Melo, T.; Garrido-Morgado, A. Corporate reputation: A combination of social responsibility and industry. Corp. Soc. Responsib. Environ. Mgmt. 2012, 19, 11-31. [CrossRef]

19. Sörgärde, N. Story-dismantling, story-meandering, and story-confirming: Organizational identity work in times of public disgrace. Scand. J. Manag. 2020, 36, 101105. [CrossRef]

20. Torres, W.J.; Bergner, R.M. Severe public humiliation: Its nature, consequences, and clinical treatment. Psychotherapy 2012, 49, 492-501. [CrossRef] [PubMed]

21. Sutton, R.I.; Callahan, A.L. The stigma of bankruptcy: Spoiled organizational image and its management. Acad. Manag. J. 1987, 30, 405-436.

22. Zahra, S.A.; Priem, R.L.; Rasheed, A.A. The antecedents and consequences of top management fraud. J. Manag. 2005, 31, 803-828. [CrossRef]

23. Caiado, R.G.G.; Quelhas, O.L.G.; Dias, J.H.d.O.; Domingos, M.d.L.C.; França, S.L.B.; Meiriño, M.J. Adherence of social responsibility management in Brazilian organizations. Soc. Responsib. J. 2018, 14, 194-212. [CrossRef]

24. Goffman, E. Embarrassment and social organization. Am. J. Sociol. 1956, 62, 264-271. [CrossRef]

25. Abdullah, Z.; Aziz, A.Y. Institutionalizing corporate social responsibility: Effects on corporate reputation, culture, and legitimacy in Malaysia. Soc. Responsib. J. 2013, 9, 344-361. [CrossRef]

26. Vergne, J.-P. Stigmatized categories and public disapproval of organizations: A mixed-methods study of the global arms industry, 1996-2007. Acad. Manag. J. 2012, 55, 1027-1052. [CrossRef]

27. Roulet, T. 'What good is wall street?' Institutional contradiction and the diffusion of the stigma over the finance industry. J. Bus. Ethics 2015, 130, 389-402. [CrossRef]

28. Porac, J.F.; Thomas, H.; Wilson, F.; Paton, D.; Kanfer, A. Rivalry and the industry model of Scottish knitwear producers. Admin. Sci. Q. 1995, 40, 203-227. [CrossRef]

29. Zimand-Sheiner, D.; Levy, S.; Eckhaus, E. Exploring negative spillover effects on stakeholders: A case study on social media talk about crisis in the food industry using data mining. Sustainability 2021, 13, 10845. [CrossRef]

30. Min, J. No pain, yet gain?: Learning from vicarious crises in an international context. J. Bus. Res. 2019, 97, 227-234. [CrossRef]

31. Choi, J.H.; Kim, S.; Yang, D.-H.; Cho, K. Can corporate social responsibility decrease the negative influence of financial distress on accounting quality? Sustainability 2021, 13, 11124. [CrossRef]

32. Ali, W.; Danni, Y.; Latif, B.; Kouser, R.; Baqader, S. Corporate social responsibility and customer loyalty in food chains-Mediating role of customer satisfaction and corporate reputation. Sustainability 2021, 13, 8681. [CrossRef]

33. Sen, S.; Bhattacharya, C.B.; Korschun, D. The role of corporate social responsibility in strengthening multiple stakeholder relationships: A field experiment. J. Acad. Mark. Sci. 2006, 34, 158-166. [CrossRef]

34. Harymawan, I.; Putra, F.K.G.; Fianto, B.A.; Wan Ismail, W.A. Financially distressed firms: Environmental, social, and governance reporting in Indonesia. Sustainability 2021, 13, 10156. [CrossRef]

35. McDonnell, M.-H.; King, B. Keeping up appearances: Reputational threat and impression management after social movement boycotts. Admin. Sci. Q. 2013, 58, 387-419. [CrossRef]

36. Corazza, L.; Truant, E.; Scagnelli, S.D.; Mio, C. Sustainability reporting after the Costa Concordia disaster: A multi-theory study on legitimacy, impression management and image restoration. Acc. Audit. Acc. J. 2020, 33, 1909-1941. [CrossRef]

37. Liang, S. National Committee of the Chinese Government Peizhi Liu: Nearly 5 Times the Increase in the Import of Milk Powder after the Sanlu Incident. Available online: http:/ / news.youth.cn/zt/11clh/lhjb/201103/t20110310_1506955.htm (accessed on 9 November 2021). (In Chinese).

38. Gao, L. Strong Supervision of Dairy Industry: Domestic Standards of Infant Milk Powder Are Stricter Than International Standards. Available online: http:/ /www.ce.cn/cysc/sp/info/201103/02/t20110302_20887749.shtml (accessed on 9 November 2021). (In Chinese).

39. Kahn, M.E. Environmental disasters as risk regulation catalysts? The role of Bhopal, Chernobyl, Exxon Valdez, Love Canal, and Three Mile Island in shaping U.S. environmental law. J. Risk Uncertain. 2007, 35, 17-43. [CrossRef]

40. Ocasio, W. Towards an attention-based view of the firm. Strateg. Manag. J. 1997, 18, 187-206. [CrossRef]

41. Greve, H.R. A behavioral theory of R\&D expenditures and innovations: Evidence from shipbuilding. Acad. Manag. J. 2003, 46, 685-702.

42. Zenebe, B. Japan's Vicious “Death by Overwork” Cycle. Available online: https://www.nupoliticalreview.com/2020/07/15 /japans-vicious-death-by-overwork-cycle/ (accessed on 21 April 2021).

43. Hiroshi, K. Confronting "Karōshi": Actions to Prevent Death from Overwork. Available online: https://www.nippon.com/en/ currents / d00310/ (accessed on 9 November 2021).

44. Milner, R. Japan's Top 10 Buzzwords for 2012. Available online: https://www.japantimes.co.jp/culture/2012/12/03/general/ japans-top-10-buzzwords-for-2012/ (accessed on 9 November 2021).

45. Umezawa, K. What Are Black Companies? | 10 Characteristics of Black Companies and the Points to Distinguish Them. Available online: https:/ / roudou-pro.com/columns/57/ (accessed on 9 November 2021). (In Japanese).

46. Beamish, P.W.; Inkpen, A.C. Japanese firms and the decline of the Japanese expatriate. J. World Bus. 1998, 33, 35-50. [CrossRef]

47. Paul, J.; Feliciano-Cestero, M.M. Five decades of research on foreign direct investment by mnes: An overview and research agenda. J. Bus. Res. 2021, 124, 800-812. [CrossRef] [PubMed] 
48. Wang, Y. Examination on philosophy-based management of contemporary Japanese corporations: Philosophy, value orientation and performance. J. Bus. Ethics 2009, 85, 1-12. [CrossRef]

49. Suto, M.; Takehara, H. Corporate social responsibility intensity, management earnings forecast accuracy, and investor trust: Evidence from Japan. Environ. Manag. 2020, 27, 3047-3059. [CrossRef]

50. Zeng, G.; Xu, Y. Sustainable development and the rating effects: A strategic categorization approach. Soc. Responsib. Corp. Soc. Responsib. Environ. Manag. 2019, 26, 1554-1564. [CrossRef]

51. Ministry of Land Infrastructure Transport and Tourism of Japan. Current Status and Issues of the Construction Industry. Available online: https: / / www.mlit.go.jp/common/001149561.pdf (accessed on 9 November 2021). (In Japanese).

52. Zou, H.; Xie, X.; Meng, X.; Yang, M. The diffusion of corporate social responsibility through social network ties: From the perspective of strategic imitation. Corp. Soc. Responsib. Environ. Manag. 2019, 26, 186-198. [CrossRef]

53. Sekarlangit, L.D.; Wardhani, R. The effect of the characteristics and activities of the board of directors on sustainable development goal (SDG) disclosures: Empirical evidence from Southeast Asia. Sustainability 2021, 13, 8007. [CrossRef]

54. Titko, J.; Svirina, A.; Tambovceva, T.; Skvarciany, V. Differences in attitude to corporate social responsibility among generations. Sustainability 2021, 13, 10944. [CrossRef]

55. Ioannou, I.; Serafeim, G. What drives corporate social performance? The role of nation-level institutions. J. Int. Bus. Stud. 2012, 43, 834-864. [CrossRef]

56. Maas, K. Do corporate social performance targets in executive compensation contribute to corporate social performance? J. Bus. Ethics 2018, 148, 573-585. [CrossRef]

57. Hausman, J.A. Specification tests in econometrics. Econometrica 1978, 46, 1251-1271. [CrossRef]

58. Croissant, Y.; Millo, G. Panel data econometrics in r: The plm package. J. Stat. Softw. 2008, 27, 1-43. [CrossRef]

59. Kato, T.; Kodama, N. Rieti Discussion Paper Series. Research Institute of Economy; Trade and Industry: Tokyo, Japan, 2016; pp. 16-E-063.

60. Sun, W.; Li, X.; Geng, Y.; Yang, J.; Zhang, Y. Board interlocks and the diffusion of csr reporting practices: The role of market development. Corp. Soc. Responsib. Environ. Manag. 2020, 27, 1333-1343. [CrossRef]

61. Piazza, A.; Perretti, F. Categorical stigma and firm disengagement: Nuclear power generation in the united states, 1970-2000. Organ. Sci. 2015, 26, 724-742. [CrossRef]

62. Tang, Z.; Tang, J. Can the media discipline Chinese firms' pollution behaviors? The mediating effects of the public and government. J. Manag. 2016, 42, 1700-1722. [CrossRef]

63. Kent, P. Shame as a social sanction in Japan: Shameful behaviour as perceived by the voting public. Jpn. Res. 1992, 3, 97-130.

64. Carberry, E.J.; King, B.G. Defensive practice adoption in the face of organizational stigma: Impression management and the diffusion of stock option expensing. J. Manag. Stud. 2012, 49, 1137-1167. [CrossRef]

65. Huang, S.; Crotts, J. Relationships between Hofstede's cultural dimensions and tourist satisfaction: A cross-country cross-sample examination. Tour. Manag. 2019, 72, 232-241. [CrossRef] 